\title{
擬似完全拘束下における高強度コンクリートの自己収縮による ひび割れポテンシャル評価に関する研究 \\ EVALUATION OF CRACKING POTENTIAL OF HIGH-STRENGTH CONCRETE INDUCED BY AUTOGENEOUS SHRINKAGE UNDER THE QUASI-COMPLETE RESTRAINT CONDITION
}

\author{
早野博幸*，丸山一平**，野口貴文***，柯木 隆**** \\ Hiroyuki HAYANO, Ippei MARUYAMA, Takafumi NOGUCHI \\ and Takashi TOCHIGI
}

\begin{abstract}
In order to evaluate the effect of autogeneous shrinkage and tensile creep property on stress of concrete under quasi-complete restraint condition as well as cracking behavior, Variable Restraint Testing Machine (VRTM) was developed. Using this machine, cracking potential of variable high-strength concrete in early ages were evaluated. According to those experiments, following results were obtained:

(1)Tensile strength of concrete was higher than splitting tensile strength, while concrete under small stress/strength ratio.

(2)Tensile strength of concrete under restrained condition was changed according to the amount of tensile creep strain. Larger amount of tensile creep strain reduced the tensile strength.
\end{abstract}

Keywords : High-strength Concrete, Autogenous Shrinkage, Crack, Tensile strength, Stress Strength Ratio, Tensile Creep 高強度コンクリート, 自己収縮, ひび割れ, 引張強度, 応力強度比, 引張クリープ

1. はじめに

近年のコンクリートはさらなる高強度化が推し進められ、設計基 準強度レベルは年々上昇する傾向にある。高強度コンクリートは、 スパンの長大化や高層化だけでなく高耐久化をも実現可能とする材 料であるが、一方で、自己収縮や温度変形などによって拘束条件の 厳しい場合にはひび割れの発生が懸念される ${ }^{11}$ 。自己収縮は、セメ ントの水和反応に起因する自己乾燥現象に基づくものと考えられて おり、本質的に不可避な収縮現象である。また、セメントの反応過 程、つまり若材踰の拘束下で許容值以上の応力やひび割れの危険性 が生じるために適切に評価する必要があり、ひび割れが生じた実物 大モデルにおいての解析的検証も行われている ${ }^{2)}$ 。

ひび割れ発生条件を評価する指標としては、割裂引張強度に対す るひび割れ発生強度の割合が挙げられ、その值は 40〜90\%と広範囲 にわたる ${ }^{3)}$ 。この割合は、比較的長期の乾燥収縮による影響を考慮 したものであり、若材齢の自己収縮を対象とした場合には水和反応 が活発である点で大きく異なるものと考えられる。また、拘束下に ある実構造物は応力履歴を受けており、ベースとなる割裂引張強度
はこの影響が反映されていない。したがって拘束条件下で水和を継 続するコンクリートの引張強度特性が不明瞭であるという本質的な 問題が含まれており、このため、拘束条件下で水和した供試体の応 カ、クリープ、強度の成分を適切に把握する必要がある。

本研究では自己収縮によるひび割れ危険性を評価する目的で、拘 束して引張応力履歴を受けた試験体の直接引張強度をもとに、擬似 完全拘束されたコンクリートの自己収縮応力を対象としたひび割れ 発生ポテンシャル評価を行った。評価に際しては、近年の性能設計 の枠組みの中で利用が図られつつある ${ }^{4)}$ 低発熱系セメントや膨張材 等の使用材料の影響についても検討を行った。これは、様々な物性 を有するセメント系材料について自己収縮ひび割れのポテンシャル を評価するという枠組みの中において広く侑瞰すること、また、各 種材料の性能設計に資するデータの取得を目的としたものである。

\section{2. 実験概要}

\section{1 コンクリートの使用材料および調合}

コンクリートの引張強度、収縮性状、クリープ性状およびこれら

\footnotetext{
*太平洋セメント㮫中央研究所 主任研究員・修士 (工学) (東京大学大学院工学系研究科建築学尃攻博士課程)

** 名古屋大学大学院環境学研究科都市環境学専攻 准教授・博士 (工学)

*** 東京大学大学院工学系研究科建築学尃攻 准教授・博士 (工学)

**** 太平洋セメント(䛈中央研究所 チームリーダー
}

Research Scientist, Research \& Development Center, Taiheiyo Cement Corporation, M. Eng. Assoc. Prof., Graduate School of Environmental Studies, Nagoya University, Dr. Eng.

Assoc. Prof., Dept. of Architecture, Graduate School of Eng., The University of Tokyo, Dr. Eng.

Leader, Research \& Development Center, Taiheiyo Cement Corporation 
の時間依存性は構成する材料の影響を受ける。コンクリートのひび 割れポテンシャルを把握する観点から、様々なセメント、混和材、 骨材種を用いるとともに、水セメント比を変化させて実験を行った。 コンクリートの使用材料を表 1 に示す。

また、コンクリートの調合を表 2、表 3 に示す。シリーズ 1 (表 2) では使用材料の種類の影響を、シリーズ 2(表 3)では普通セメントを 用いて水セメント比の影響をそれぞれ検討することとした。調合条 件は粗骨材絶対容積を $0.34 \mathrm{~m}^{3} / \mathrm{m}^{3}$ 、空気量を $2 \%$ 、スランプフローを $60 \pm 10 \mathrm{~cm}$ とし、コンクリートは $100 \mathrm{l}$ パン型ミキサを使用してモル タルを 90 秒間練り混ぜ、その後、粗骨材を投入して 90 秒間練り混 ぜ、排出した。

\section{2 収縮試験}

\section{(1)自由収縮試験}

自由収縮試験は、日本コンクリート工学協会で提案されている「セ メントペースト、モルタル及びコンクリートの自己収縮及び自己膨 張試験方法」 ${ }^{5)}$ に準じて行った。型枠底部には摩擦低減のためテフ ロンシートを敷き、ポリエステルフィルムで密閉したコンクリート $(100 \times 100 \times 400 \mathrm{~mm})$ のひずみを低圧型接触変位計 $(反 力 0.25 \mathrm{~N})$ で測定 した。

(2)擬似完全拘束試験

表 1 使用材料

\begin{tabular}{|c|c|c|c|}
\hline 種類 & 記号 & 材料名 & 物性および成分 \\
\hline \multirow[t]{6}{*}{ セメント } & NC & 普通ポルトランドセメント & 密度 $3.16 \mathrm{~g} / \mathrm{cm}^{3}$ ，比表面積 $3290 \mathrm{~cm}^{2} / \mathrm{g}$ \\
\hline & BBC & 高炉セメントB種 & 密度 $3.04 \mathrm{~g} / \mathrm{cm}^{3}$ ，比表面積 $3810 \mathrm{~cm}^{2} / \mathrm{g}$ \\
\hline & MC & 中庸熱ポルトランドセメント. & 密度 $3.21 \mathrm{~g} / \mathrm{cm}^{3}$ ，此表面積 $3200 \mathrm{~cm}^{2} / \mathrm{g}$ \\
\hline & LC & 低熱ポルトランドセメント & 密度 $3.22 \mathrm{~g} / \mathrm{cm}^{3}$ ，比表面積 $3360 \mathrm{~cm}^{2} / \mathrm{g}$ \\
\hline & SFPC & シリカフュームプレシックスセメント & 密度 $3.07 \mathrm{~g} / \mathrm{cm}^{3}$ ，比表面積 $6190 \mathrm{~cm}^{2} / \mathrm{g}$ \\
\hline & $E C$ & エコセメント & 密度 $3.17 \mathrm{~g} / \mathrm{cm}^{3}$ ，比表面積 $4100 \mathrm{~cm}^{2} / \mathrm{g}$ \\
\hline \multirow[t]{2}{*}{ 粗骨材 } & CS & 碎石(青梅産) & 表乾密度 $2.64 \mathrm{~g} / \mathrm{cm}^{3}$ ，吸水率 $0.60 \%$ \\
\hline & LS & 石灰石(藤原産) & 表乾密度 $2.70 \mathrm{~g} / \mathrm{cm}^{3}$ ，吸水率 $0.71 \%$ \\
\hline 細骨材 & $s$ & 陸砂(大井川水系産) & 表乾密度 $2.59 \mathrm{~g} / \mathrm{cm}^{3}$ ，吸水率 $1.97 \%$ \\
\hline \multirow[t]{2}{*}{ 混和材 } & EX & 膨張材 & 石灰系早強型, 密度 $3.19 \mathrm{~g} / \mathrm{cm}^{3}$ \\
\hline & SP & 高性能 $\mathrm{AE}$ 減水刘 & ポリカルボン酸エーテル系 \\
\hline
\end{tabular}

表 2 コンクリートの調合（シリーズ 1 : 使用材料の影響）

\begin{tabular}{|c|c|c|c|c|c|c|c|c|c|}
\hline \multirow{2}{*}{ 記号 } & \multirow{2}{*}{$\begin{array}{c}W / C \\
(\%)\end{array}$} & \multirow{2}{*}{$\begin{array}{l}\text { s/a } \\
(\%)\end{array}$} & \multirow{2}{*}{$\begin{array}{c}\text { 空気量 } \\
\text { (\%) }\end{array}$} & \multicolumn{5}{|c|}{ 紧位吾 $\left(\mathrm{kg} / \mathrm{m}^{3}\right)$} & \multirow{2}{*}{$\begin{array}{c}f c 28 \\
\text { (封かん) }\end{array}$} \\
\hline & & & & w & $\mathrm{C}$ & EX & $\mathrm{s}$ & $\mathrm{G}$ & \\
\hline N25 & \multirow{8}{*}{25} & 44.9 & \multirow{8}{*}{2.0} & \multirow{8}{*}{160} & \multirow{6}{*}{640} & - & 719 & \multirow{7}{*}{903} & 98.6 \\
\hline BB25 & & 44.2 & & & & - & 698 & & 95.5 \\
\hline M25 & & 45.2 & & & & - & 727 & & 101.3 \\
\hline $\mathrm{L} 25$ & & 45.3 & & & & - & 729 & & 96.4 \\
\hline SFP25 & & 44.4 & & & & - & 704 & & 101.5 \\
\hline E25 & & 45.0 & & & & - & 721 & & 95.8 \\
\hline NEX25 & & 44.9 & & & 610 & 30 & 717 & & 96.9 \\
\hline LS25 & & 44.9 & & & 640 & - & 719 & 919 & 94.3 \\
\hline
\end{tabular}

※)記号は、吕(使用材料の種類) 25 (水セメント比)

表 3 コンクリートの調合（シリーズ $2: \mathrm{W} / \mathrm{C}$ の影響）

\begin{tabular}{|c|c|c|c|c|c|c|c|c|}
\hline \multirow{2}{*}{ 記号 } & \multirow{2}{*}{$\begin{array}{c}\text { W/C } \\
(\%)\end{array}$} & \multirow{2}{*}{$\begin{array}{l}\mathrm{s} / \mathrm{a} \\
(\%)\end{array}$} & \multirow{2}{*}{$\begin{array}{c}\text { 空気量 } \\
(\%)\end{array}$} & \multicolumn{4}{|c|}{ 単位国 $\left(\mathrm{kg} / \mathrm{m}^{3}\right)$} & \multirow{2}{*}{$\begin{array}{c}f c 28 \\
\text { (封かん) }\end{array}$} \\
\hline & & & & $w$ & C & $\mathrm{s}$ & $\mathrm{G}$ & \\
\hline $\mathrm{N} 20$ & 20 & 40.0 & \multirow{4}{*}{2.0} & \multirow{4}{*}{160} & 800 & 588 & \multirow{4}{*}{903} & 108.4 \\
\hline N25 & 25 & 44.9 & & & 640 & 719 & & 98.6 \\
\hline N30 & 30 & 47.8 & & & 534 & 807 & & 83.8 \\
\hline N35 & 35 & 49.7 & & & 458 & 869 & & 72.4 \\
\hline
\end{tabular}

コンクリートを擬似的に完全拘束する試験としては、図 1 に示す 可変拘束応力試験機 VRTM $^{6}$ （Variable Restraint Testing Machine）を 用いた。本試験機は、中央に打ち込まれたコンクリートの試験区間 (長さ $500 \mathrm{~mm}$ 、断面 $100 \times 100 \mathrm{~mm}$ ) の硬化過程における変位ならびに 応力状態をモニタリングし、クロスヘッドを任意に制御することに よって様々な拘束条件を擬似的に再現することができる。擬似完全 拘束試験は、コンクリート試験体を外部からの拘束によって変位を 一定変位以下に制御するもので、自己収縮を対象とした場合にはひ び割れが最も発生しやすい条件を実現するものであり、コンクリー トの自己収縮ひび割れを対象としたポテンシャルを計測する試験と

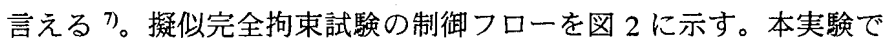
は、予め制御の基準となるひずみトリガー、応カトリガーを設定す る。まず、クロスヘッドを固定しておき、材齢とともにコンクリー トが収縮すると、ひずみおよび応力が生じる。これらが增大し応力 がトリガー值に達すると、応力をキャンセルする方向にクロスヘッ ドが動く。これを繰り返すことで、一定応力内でコンクリートを擬 似的に自由変形させる。すなわち、ステップ 1 では応力トリガー制 御のもとでコンクリートを自由変形させる。ステップ 2 では、コン クリートに発生する応力はトリガー内で制御されるが、ひずみは収 縮ひずみおよびクロスヘッドの移動の繰り返しによって增大し、図 2 のA 点のように設定したひずみトリガーに達すると、 ひずみが 0 になる B 点までクロスヘッドが移動する。こ のステップ 1 および 2 を 1 サイクルとし、次サイクルか

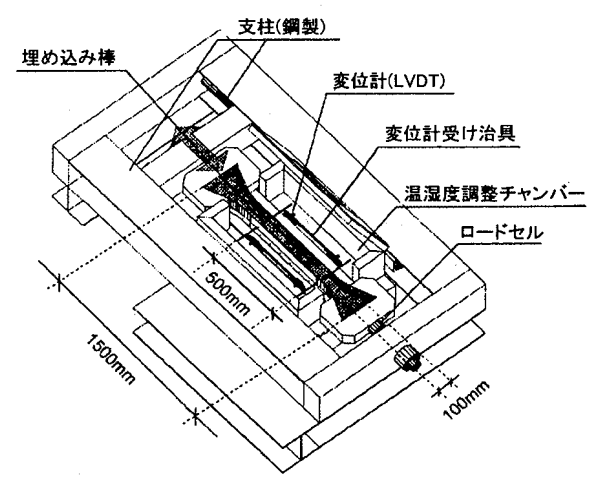

図 1 VRTM の概要
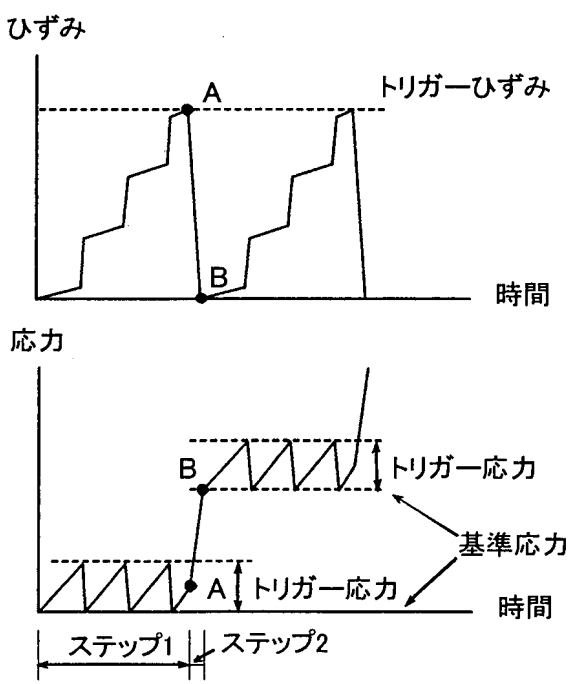

図 2 擬似完全拘束の制御フロー 
らは B 点の応力を基準応力として制御を繰り返すことで、コンクリ 一トの測長区間変位をひずみトリガー值以内に保持する。なお、各 トリガー值は既往の研究 6)を参考にしてひずみトリガーを $4 \mu$ 、応 カトリガーを $0.01 \mathrm{~N} / \mathrm{mm}^{2}$ に設定した。クロスヘッド制御は $50 \mathrm{msec}$ インターバルで実施し、クロスヘッド移動速度は材齢 1 日までは $0.005 \mathrm{~mm} / \mathrm{min}$ 、それ以降は $0.003 \mathrm{~mm} / \mathrm{min}$ とした。

\section{3 強度試験}

VRTM で材齢 7 日の測定終了後、クロスヘッド移動速度 $0.003 \mathrm{~mm} / \mathrm{min}$ でコンクリート試験体の直接引張試験を行い、ひび割 れ発生までの引張強度を試験体 2 体について測定してその平均をひ び割れ発生強度とした。併せて、材齢 $1 、 3 、 7$ 日に $\phi 10 \times 20 \mathrm{~cm}$ の封 縅供試体で割裂引張試験、材齢 1、3、7、28 日に圧縮強度試験およ びヤング係数の測定を行った。また、ヤング係数の測定は別途材齢 7 日において VRTM による圧縮載荷および引張載荷時にも行い、 VRTMに設置している変位計と測定区間のコンクリート両側面中央 に貼付したひずみゲージの值による算出をそれぞれ行い、圧縮載荷 時の円柱供試体のヤング係数と比較した。

\section{3. 実験結果および考察}

\section{1 自由収縮ひずみ}

各コンクリートの凝結始発時からの自由収縮ひずみを図 3 に示す。 左図のシリーズ 1 における使用材料の影響に関しては、膨張コンク リート(NEX)以外は収縮側の值を示し、材齢 7 日の時点で収縮ひず

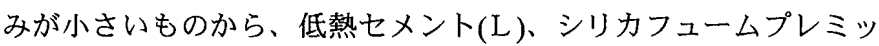
クスセメント(SFP)、中庸熱セメント(M)、石灰石(LS)、普通セメン ト $(\mathrm{N}) 、$ 高炉セメント B 種(BB)、エコセメント(E)を使用したコンク リートの順になった。なお、L、SFP、Mについては材齢 7 日でほぼ 収束する傾向となったが、その他では材龄 7 日以降も収縮量が増加 する傾向があるものと考えられる。右図の水セメント比の影響に関 しては、水セメント比の減少とともに自己収縮ひずみは增大する結
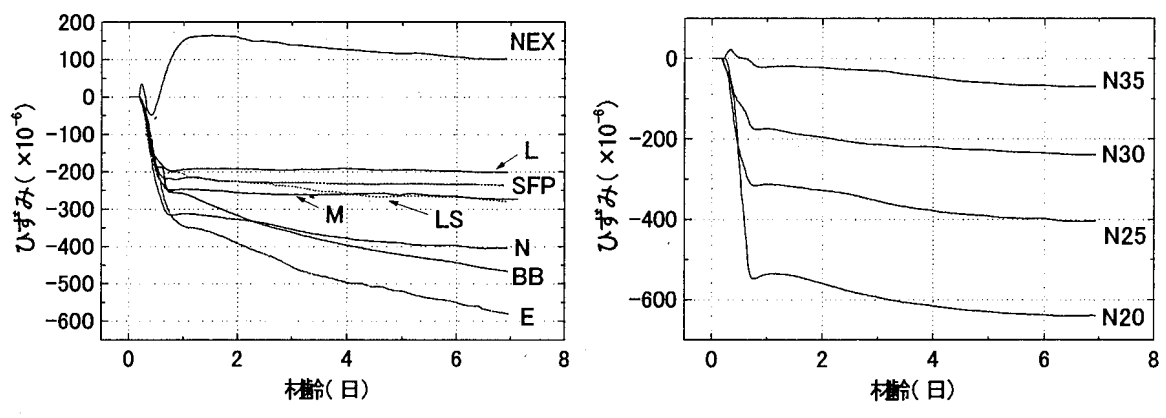

図 3 各コンクリートの自由収縮ひずみ(左 : シリーズ 1, 右 : シリーズ 2)
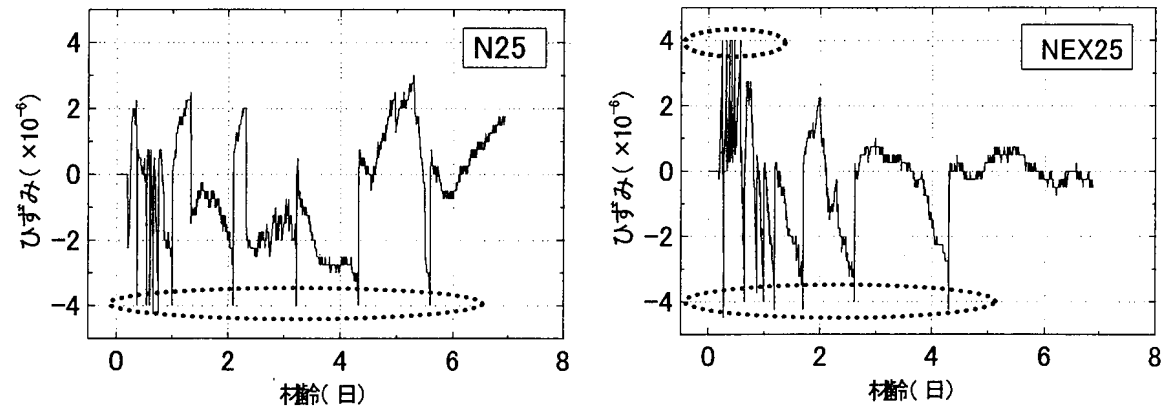

図 4 ひずみの変化（左 : N25, 右 : NEX25）
果となった。

\section{2 擬似完全拘束下における各種物性}

擬似完全拘束試験でのひずみ挙動の一例として、普通コンクリー ト(N) と膨張コンクリート(NEX)の結果を併せて図 4 に示す。 $\mathrm{N}$ の 場合は材齢初期から収縮ひずみが生じるため、収縮側でひずみトリ ガーとなる $4 \mu$ (図中の点線内)に達すると 0 に戻るというサイクル が繰り返されているが、NEXでは自己収縮ひずみよりも膨張ひずみ が上回るために、材齢初期の 0.4 日程度までは膨張側のひずみでほ ぼ制御されていることがわかる。NEXではその後、収縮側のトリガ 一制御に変わり、両者ともにひずみトリガ一内で擬似的な完全拘束 制御が実施されていることが確認できる。なお、ひずみトリガーが 作動した点を図中の点線で示したが、応カトリガーは $0.01 \mathrm{~N} / \mathrm{mm}^{2}$ と 小さく設定しており、その除荷に伴うひずみ変化は非常に微小なも のであるため、図からは読み取ることができない。

VRTM のクロスヘッド移動により測定した試験体の引張ヤング係 数について検討を行った。材龄 7 日の N25 の VRTM 試験体を用い、 側面に貼付したひずみゲージでの引張および圧縮ヤング係数と VRTM 変位計での引張ヤング係数をそれぞれ測定した結果を図 5 に 示す。算出方法は原点からの割線ヤング係数とし、同調合、同材踰 となる円柱供試体の圧縮ヤング倸数と比較した。既往の研究では、

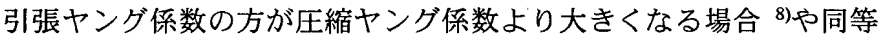
となる報告 9があるが、本結果では引張ヤング係数の方が若干では あるが大きくなる傾向はみられるものの、すべてほぼ同等とみなし てよく、円柱供試体の結果とも差異はみられないことから円柱供試 体の圧縮ヤング係数が適用できるものと考える。

続いて VRTMにおける応力挙動に関して再現性を確認するため、 若材路時でひずみ変化の大きい BB と NEXの 2 回の試験結果を一例 として図 6 に示す。VRTM における応力挙動は、ある一定範囲内で 推移する応力トリガー制御によるものと、その後トリガーひずみに 達してクロスヘッド移動による完全拘束制御が行われて応力が急増 するひずみトリガー制御の 2 種類のステップ で構成される。したがって材齢と応力の関係 は階段状に似た形状となる。図の BB の例の ように、高強度コンクリートは材齢 1 日程度 までの自己収縮ひずみの変化が大きいため初 期は頻繁にひずみトリガーに達するが、その 時間的間隔が短く、さらに初期材齢のヤング

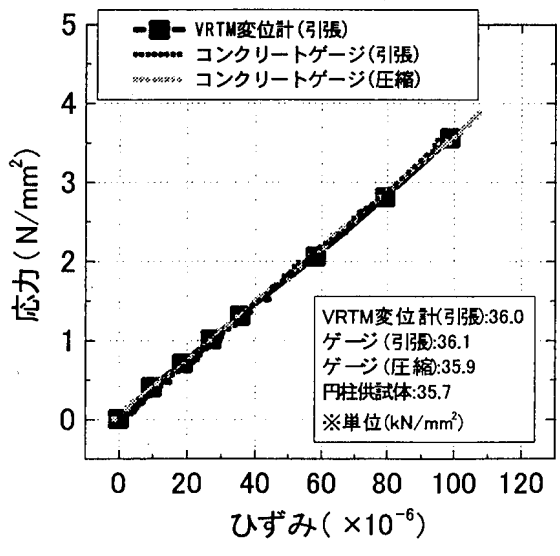

図 5 測定したヤング係数の比較 
倸数が小さいことから态力変化も微増であり、その階段の形状は相 対的に小さくなる。材秢後半になるにしたがって、今度は逆に自己 収縮ひずみの増分が小さくヤング保数は大きくなるため、大きな階 段状となる挙動を示すようになる。また、再現性については、2 回 の試験で材齢 7 日時の応力差は NEX で 13\%、BB では $8 \%$ 程度であ り、過程の挙動をみても大きな差異はないことが確認された。

次に、各コンクリート (シリーズ 1 のセメント種類の影響、ひび 割れ抑制材料の影響、シリーズ 2 の水セメント比の影響)における収 縮応力の変化を図 7 に示す。これらはすべて 1 回目の試験結果を示 し、比較として 25 をすべてに図示した。セメント種類の影響に関 しては、低発熱系の L、SFP は共に材龄 7 日の自己収縮応力は $1.0 \mathrm{~N} / \mathrm{mm}^{2}$ 以下と小さく、続いて $\mathrm{M} 、 \mathrm{~N}$ の順に大きくなり、 $\mathrm{BB}$ と $\mathrm{E}$ に関してはそれぞれ材齢 6.9 日および 5.1 日にひび割れが発生して 応力がほぼ 0 に低下した。この 2 種類のセメントは、図 3 の自己収 縮ひずみの傾向からわかるように、材跲 1 日程度までは他と同様に 自己収縮ひずみは増大しているが、若材㱓であるためにこれに相当 する収縮応力の変化は小さい。しかし、それ以降の挙動は他と大き く異なり、硬化体の骨格が形成され剛性が高くなっていく材龄後半 についても自己収縮ひずみは継続して增えていくことが確認できる。 その結果、自己収縮応力が増大しひび割れ発生に至ったと考えられ る。ひび割れ抑制材料に関しては、石灰石骨材を使用した場合は材 齢0.75日まではNと同様な挙動であったが、その後若干の差が生じ、 膨張材を使用した場合は初期から圧縮応力が導入され、材踰 0.6 日 程度で最大 $0.86 \mathrm{~N} / \mathrm{mm}^{2}$ の圧縮応力となった後、以降引張応力側に転 じた。 $\mathrm{N}$ と比較した場合には、材齢 7 日時においてそれぞれ $0.4 \mathrm{~N} / \mathrm{mm}^{2}$ $2.6 \mathrm{~N} / \mathrm{mm}^{2}$ の自己収縮応力の低減が可能となる。水セメント比の影響 に関しては、水セメント比の減少とともに材跲 7 日の収縮応力が増 大していることは明らかであり、また、発生する応力はコンクリー トの自己収縮ひずみによる収縮応力増加とクリープ・リラクゼーシ ヨンによる応力緩和現象のバランスで決定され、応力の減少してい る部分は後者が上回っているものと推察できる。

\section{3 強度特性によるひび割れポテンシャル評洒の検討}

材齢 7 日まで疑似完全拘束下での測定を行った後、クロスヘッド の強制移動による試験体の引張載荷を行い、ひび割れ発生強度の測 定を行った。直接引張試験に関しては偏心などの影響によるばらつ きが予想されるが、本試験では試験体を作成してから引張治具に固 定するのではなく引張試験機に直接コンクリートを打ち込む形にな るため、すべてのコンクリートで条件は同じであり、その影響は小 さい。実際に引張試験時の硬化コンクリートの左右にひずみゲージ
を貼付し、偏心が生じていないことを確認するとともに、N25 の標 準調合で材齢 7 日においてばらつきの検討を行った。直接引張強度 $\left(\mathrm{N} / \mathrm{mm}^{2}\right)$ は変動係数 0.046 (標準偏差 $\left.0.189 、 \mathrm{n}=4\right)$ 、割裂引張強度は変 動係数 0.065 (標準偏差 $0.278 、 n=6$ ) であり、本検討において直接引張 強度は割裂引張強度のばらつきより若干小さいものとなった。また、 定着部には組立て鉄筋を配しているため、端部でひび割れ破断は生 じていない。

コンクリートのひび割れ発生危険度を評価する指標としては、同 じ材齢の割裂引張強度に対するひび割れ発生強度の比(ひび割れ強 度/割裂引張強度)が挙げられ、その割合は様々な実験要因の影響に より広範囲にわたっている。この割裂引張試験をべースとした指標 は、コンクリート試験体自体が応力履歴を全く受けていないため、 通常の構造物のひび割れ発生という過程を考えた場合には、引張応 力の継続とクリープによる応力緩和という要素が久けている。また、 これらは全ての調合で同一ではなく、拘束を与えることによってそ のコンクリート固有の自己収縮や剛性などの時系列的変化が応力履 歴となって表れることになり、コンクリートの自己収縮特性に応じ た拘束条件が自然と与えられることになるといえる。本研究ではこ れらを勘案し、拘束を与えることによって応力履歴を受けた試験体 の直接引張試験を行い、自己収縮応力がひび割れ発生強度のどの程 度の割合となるかという直接引張強度をべースとした応力強度比に 基づいたひび割れ発生ポテンシャルを各コンクリートにおいて評価 した。

材齢 7 日における直接引張強度と割裂引張強度を比較した結果を

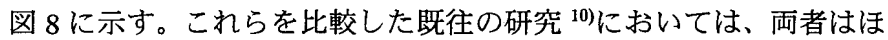
ぼ同等という結果が得られており、ともに試験で偏心などが生じな ければ本質的に同一と考えられる。本研究と異なるのは、直接引張 試験体が拘束を受けることによって応力履歴を受けている点であり、

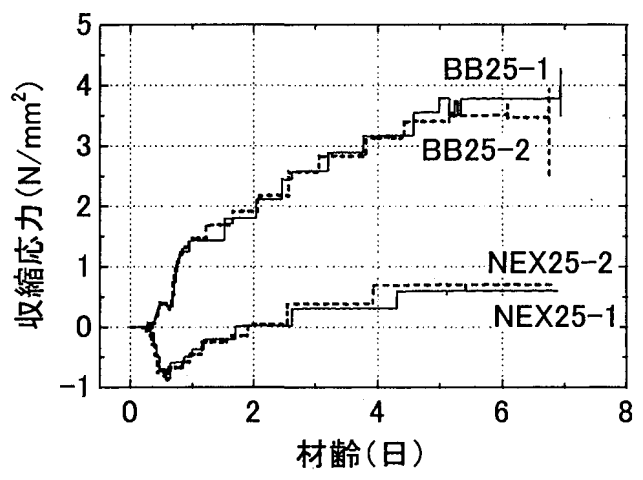

図 6 収縮応力の再現性の検討 (BB，NEX)
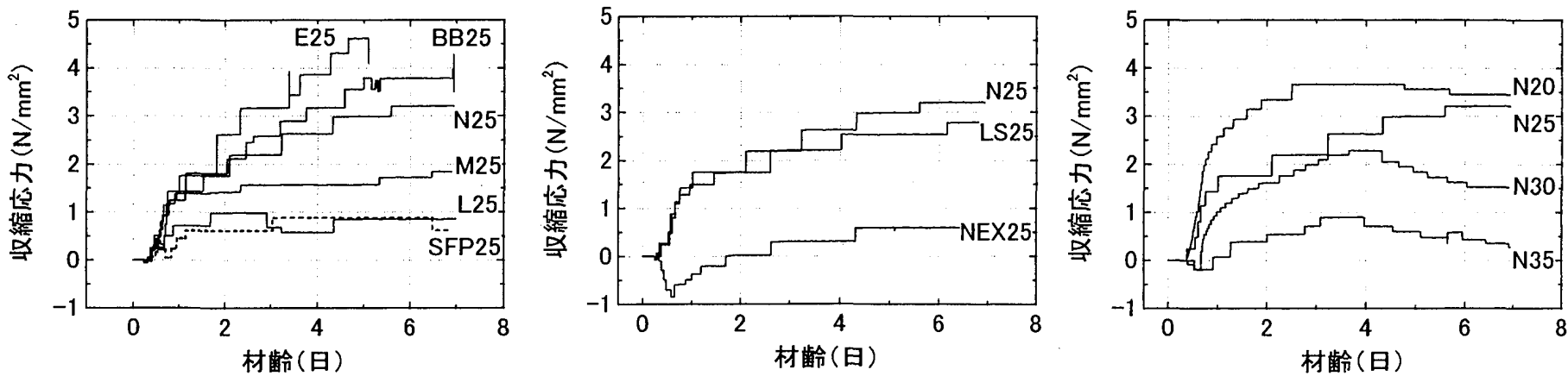

図 7 収縮応力の変化（左：セメント種類の影響，中：ひび割れ抑制材料の影響，右 : 水セメント比の影響） 
結果は調合によって異なる傾向を示した。シリーズ 1 の NEX25に ついては、直接引張強度が割裂引張強度を $15 \%$ ほ 上回ったが、直 接引張試験体の膨張ひずみを完全拘束したことによる組織の緻密化 の効果 $\left.{ }^{11}\right)$ が引張強度增進につながったと思われる。NEX25 を除くと、 図の点線のようにやや直接引張強度の方が高い傾向を示した。シリ ーズ 2 については、 $\mathrm{N} 20$ は直接引張強度の方が $0.58 \mathrm{~N} / \mathrm{mm}^{2}$ 低下して おり、ばらつきについて事前検討した標準偏差が本調合でも同等で あると仮定すると、偏差は直接引張、割裂引張ともに $2 \sigma$ 以上とな っていることから、ばらつきを考慮しても実際に強度低下が生じて いる可能性が高い。N20 は、図 7 をみるとわかるように若材齢から 継続して高い収縮応力が生じているため、この影響があらわれたも のと考えられる。N25についても同様に直接引張強度の方がやや小 さくなっており、シリーズ 2 だけ見た場合は、強度が高くなると図 の曲線のような傾向となる。これらの傾向については応力履歴との 関連性が重要であるため、後に考察を付け加えることとする。

材齢 7 日の応力強度比によるひび割れ発生ポテンシャル評価結果 を図 9 に示す。シリーズ 1 の使用材料の比較に関しては、BB25(材. 齢 6.9，6.7 日にひび割れ)および E25(同 5.1，4.3 日)についてはいず れもひび割れが発生したため $100 \%$ となるその他では N25 の収縮 応力が直接引張強度の約 $80 \%$ を占め比較的高い割合となっており、 続いて LS25、M25 となり、低発熱系セメントの L25、SFP25 が 20\% 程度と低い割合で自己収縮ひずみ量と同様の傾向を示した。自己収 縮ひずみは鉱物組成のうち $\mathrm{C}_{2} \mathrm{~S}$ が多いほど小さいといわれており ${ }^{12)}$ 低発熱系セメントは $\mathrm{C}_{2} \mathrm{~S}$ 量が多いため自己収縮ひずみは小さくなる が、一方で強度発現性が遅く引張強度についても同様な傾向を示す ため、応力強度比でみたひび割れ発生ポテンシャル評価という観点 からは判断が難しいところである。しかし、本実験結果より、低発 熱系セメントの強度発現性が遅いという欠点をカバーするだけの自 己収縮応力の低減効果が定量的に明らかに なったといえる。また、この中では NEX25 が最も低い值を示し、前述した引張強度の 増進と材齢初期の膨張応力導入による自己 収縮応力低減効果が奇与する形となった。 シリーズ 2 に関しては、水セメント比の減 少とともにひび割れ発生の危険性は高くな るといえるが、N20 と N25 はそれほど大差 ない結果となった。すべての調合の中で自 己収縮ひずみが最大となった $\mathrm{N} 20$ で応力強 度比が約 80\%となりひび割れは生じなかっ たが、それより自己収縮ひずみの小さい BB25 と E25 ではひび割れが生じる結果と なった。

また、若材齢の経時的変化におけるひび 割れポテンシャル評価を行うため、割裂引 張強度試験の結果と同様な引張強度発現比 を試験体が生じるものと仮定して、材齿 1 、 3、7日における引張強度を求め、応力強度 比の推移として図 10 に示す。シリーズ 1 の材料種類の比較については、M を含む低 発熱系セメントおよび NEX の応力強度比
はいずれも低い割合で推移し、材齢 3 日から 7 日にかけて大きな変 化はみられない。擬似完全拘束下でこのような低い応力強度比であ れば、低発熱系セメントの自己収縮発現が材踰 7 日でほぼ収束して いることも勘案すると、実構造物の拘束下では自己収縮応力のみの 要因でひび割れが発生する可能性は非常に小さいと考えることがで きる。一方、その他のコンクリートは材齢とともに応力強度比は高 くなっていき、きわめて高くなった一部の調合(BB25，E25)ではひ び割れが発生した。長期材齢のコンクリートに関しては、応力強度

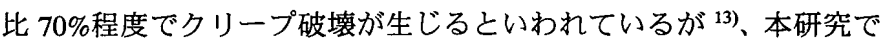
は BB や E では既に材㱓 3 日から 70\%以上の応力強度比を示してい るものの、すぐにひび割れ発生には至っていない。若材齢時と長期 材秢時で異なる点は、水和が活発に進行しているか否かという大き な相違があり、これらが大きな影響を及ぼていることが考えられ る。

シリーズ 2 の水セメント比の影響に関しては、N35 および N30 は 材齢 1 日では自己収縮応力が小さいためひび割れ発生の危険性はか なり小さく、材齢 3 日ではやや增加するが、その後はクリープの影 響のため応力自体がやや低下し、一方で引張強度が増加するため、 材齢 7 日ではひび割れは発生しにくい状況となる。N25 は、材齢と ともに応力強度比は上昇し、引張強度の増進よりも自己収縮応力の 増加割合が大きいことを示している。N20に関しては、材齢 1 日か ら継続して応力強度比が 80〜90\%の間にあり高い応力履歴を受けて はいるが、BB などのようにひび割れ強度に達してはいないためひ び割れ発生には至らない。以上より、自己収縮ひずみの絶対值がひ び割れに直接結び付くものではないが、少なくとも自己収縮の小さ い低発熱系セメントや膨張コンクリートでは自己収縮に起因するひ び割れの危険性は低いことが明らかとなった。

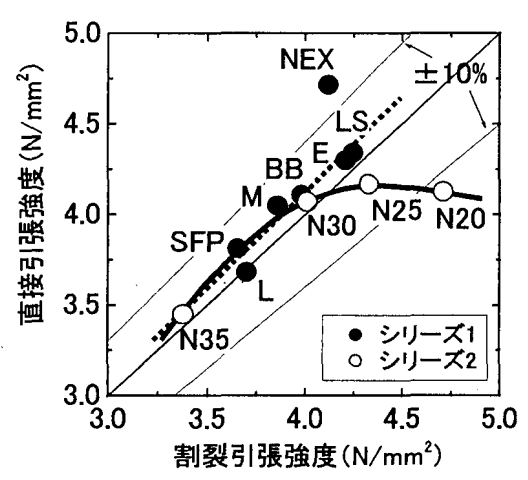

図 8 引張強度の比較

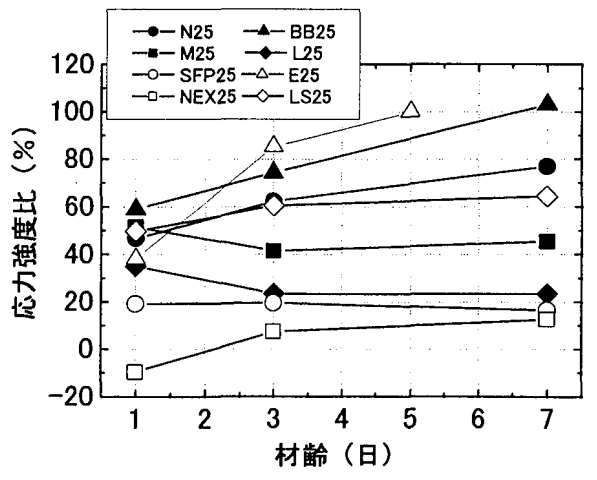

図 10 応力強度比の推移（左: シリーズ 1, 右 : シリーズ 2)

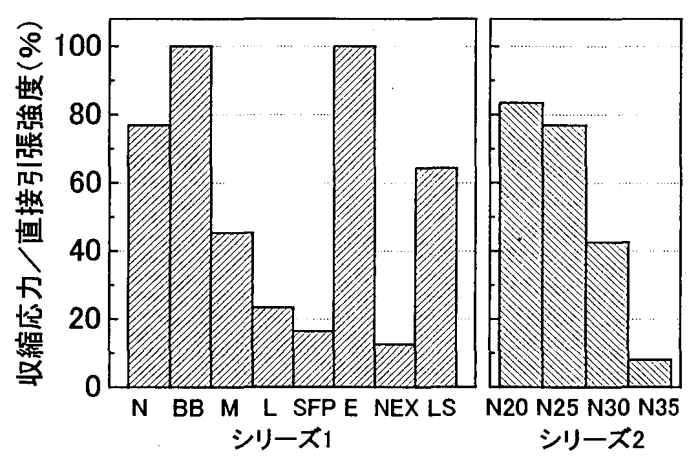

図 9 ひび割れポテンシャル評価結果

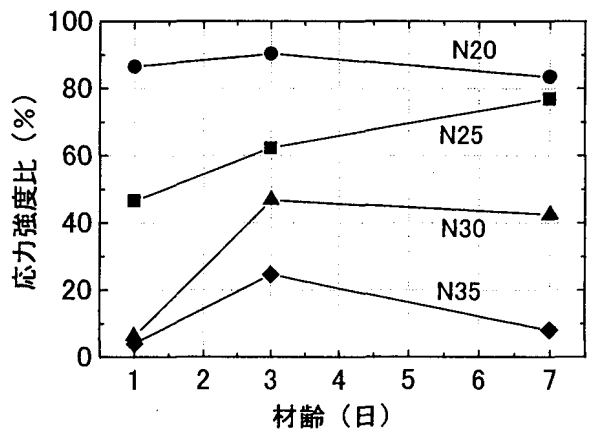


3.4 引張クリープ特性およびひび割れ発生に影響を及ぼす各種要因の 考察

自己収縮応力で生じるひび割れは自己収縮ひずみの大小のみが 影響するものではなく、剛性を含む引張強度特性や引張クリープ特 性が大きく関与するものと考えられる。完全拘束下のひずみに関し ては、TSTM における Kovler ${ }^{14)}$ の提案した概念図を図 11 に示すよう に、トリガー応力の範囲内でのある一定応力下におけるひずみと、 そのひずみがトリガーひずみに達した場合、クロスヘッド制御によ ってひずみを 0 に戻す弾性ひずみによって構成されている。前者は 比較的長期間にわたって生じる収縮ひずみとクリープひずみが含ま れ、この和と制御時の弾性ひずみがひずみトリガ一制御終了時に等 しくなる。そのため、この累積值と別途測定した自由収縮ひずみと の差分によりクリープひずみを求めることができる。ただし、この クリープは一般的にいう一定応力下のものでなく、コンクリートの 自己収縮に応じて蓄積される変動応力下におけるクリープひずみの 総和を表わすものとなる。以上が Kovler の示した概念を説明したも のであるが、これ以外の知見として、各々のステップにおける弾性 ひずみはその制御時に完全拘束を再現するものであるため、ひずみ を 0 と考えるとその材㱓における引張拘束ひずみと考えることがで きる。ここでは、自己収縮ひずみ、累積クリープひずみ (クリープ ひずみの総和)および累積引張拘束ひずみと収縮応力の関係からコ ンクリートのひび割れ発生過程との関連性について検討した。本実 験では、ひび割れの発生直前においてもひずみおよび応力挙動を細 かくモニタリングしているため、この点も併せて考察を加える。

自己収縮ひずみと収縮応力の関係をシリーズ 1 のひび割れが発生 した調合およびシリーズ 2 について図 12 に示す。なお、直接引張強 度(ひび割れ強度)の值も図中に併記した。まず、自己収縮ひずみ自 体が小さい N35 を除く調合では $100 \mu$ 前後で応力が発生しており、
それ以下となる応力に寄与しない自己収縮ひずみが存在する。また、 各々の調合における自己収縮ひずみ一応力曲線の勾配は見掛けのヤ ング係数を表わすものであるが、材齢の進行に伴う自己収縮の增大 とともに収縮応力が緩やかに増加する範囲から急激な増加を示す範 囲に移行する点、すなわち見掛けのヤング係数が大きく変化する屈 曲点が存在する(図中の○)。これ以降の自己収縮ひずみは応力に大 きく寄与することを示すものであり、この点について検討を行った。 検討項目は、図では時間依存性が示せないため届曲点の材㮆、その 時点の自己収縮ひずみおよび応力に影響するヤング係数とした。な お、若材齢のヤング係数は既往の研究 ${ }^{15)}$ を参考にした式(1)に本実験 データを代入して $\mathrm{S}_{\mathrm{E}}$ および $\mathrm{a}_{\mathrm{E}}$ を定め、算出した。

$E(t)=E_{28} \cdot \exp \left\{S_{E}\left[1-\left(\frac{28-a_{E}}{t-a_{E}}\right)^{0.5}\right]\right\}$

ここに、 $\mathrm{E}(\mathrm{t})$ : 有効材榆 $\mathrm{t}$ 日のヤング係数 $\left(\mathrm{N} / \mathrm{mm}^{2}\right) 、 \mathrm{E}_{28}$ : 材齢 28 日の ヤング係数 $\left(\mathrm{N} / \mathrm{mm}^{2}\right) 、 \mathrm{~S}_{\mathrm{E}}$ : 調合の係数、 $\mathrm{a}_{\mathrm{E}}$ : 凝結時間の影響による係 数(日)、 $\mathrm{t}$ :有効材齢(日)とする。図中の屈曲点に関して算出した詳細 を表 4 に示すが、材齢に関してはN35を除いて自己収縮ひずみが大 きい調合ほど長くなっており、そのときのヤング係数も同様に大き い傾向を示している。自己収縮ひずみについては、全自己収縮ひず みと屈曲点における自己収縮ひずみの全体に対する割合も括弧内に 記載した。ひび割れの生じた BB25 と E25 では屈曲点以降のその割 合は高く、N30やN 35 もその割合は高いものの駆動力となる自己収 縮自体が小さいので大した応力は発生しない。 20 に関しては初期 の見掛けのヤング係数が小さいことから、屈曲点までのクリープ量 は非常に大きいことが予測できるが、屈曲点以降の自己収縮ひずみ 量の割合は低い結果となった。コンクリートのヤング係数が小さい 若材秢時に生じる自己収縮ひずみは、応力増大に奇与するものでは
表 4 見掛けのヤング係数に おける届曲点の詳細

\begin{tabular}{c|c|c|c}
\hline 調合 & $\begin{array}{c}\text { 村龄 } \\
(\text { 日 })\end{array}$ & $\begin{array}{c}\text { 自己収縮ひずみ } \\
\left(\times 10^{-6}\right)\end{array}$ & $\begin{array}{c}\text { ヤング係数 } \\
\left(\mathrm{kN} / \mathrm{mm}^{2}\right)\end{array}$ \\
\hline $\mathrm{N} 20$ & 1.732 & $641(85.7 \%)$ & 31.4 \\
\hline E25 & 0.760 & $582(53.6 \%)$ & 24.6 \\
\hline BB25 & 0.670 & $467(49.1 \%)$ & 19.2 \\
\hline N25 & 0.534 & $404(61.6 \%)$ & 17.5 \\
\hline N30 & 0.548 & $239(51.5 \%)$ & 15.0 \\
\hline N35 & 1.900 & $70(31.6 \%)$ & 25.9 \\
\hline
\end{tabular}

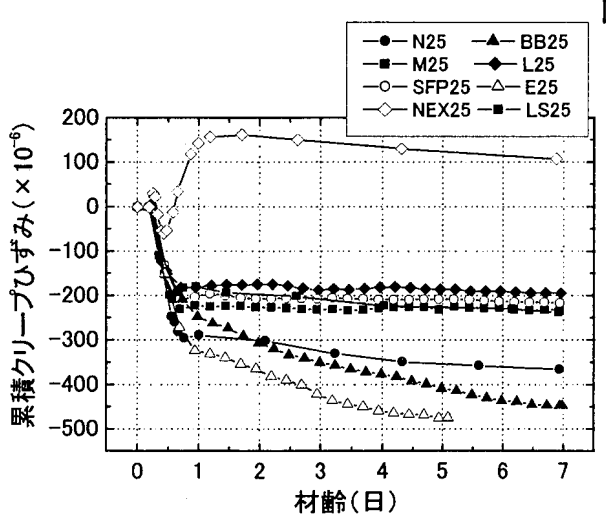

図 11 擬似完全拘束下におけるひずみの概要 ${ }^{13)}$

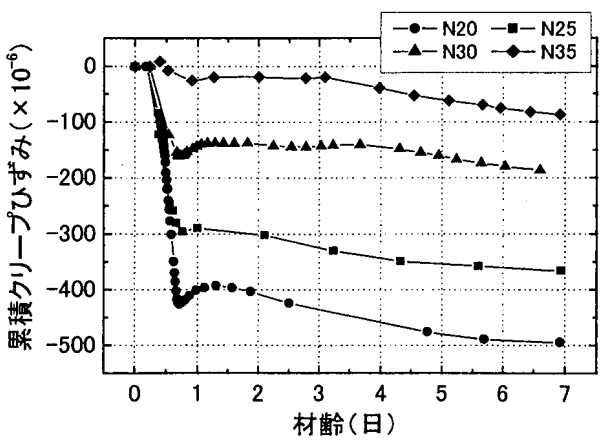

図 13 累積クリープひずみと材齢の関係（左：シリーズ 1, 右 : シリーズ 2)

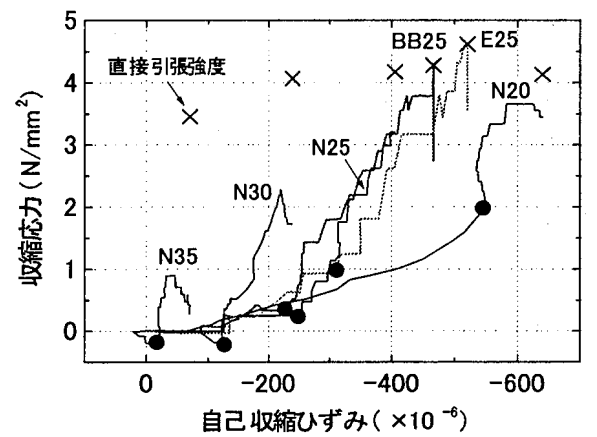

図 12 自己収縮ひずみと収縮応力の関係

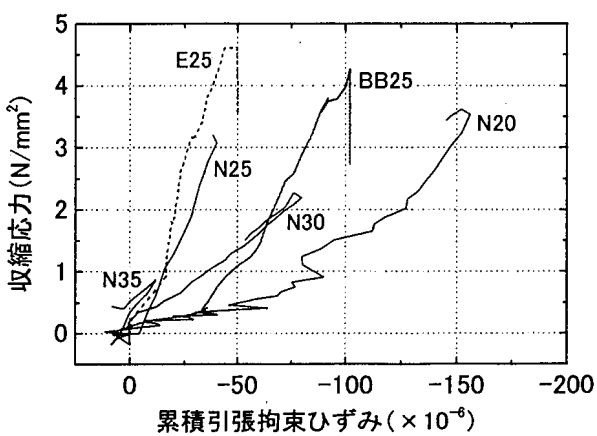

図 14 .累積引張拘束ひずみと収縮応力の関係 
なく、硬化体の骨格が形成され、剛性がある程度高くなる材齢以降、 すなわち屈曲点以降の自己収縮ひずみの変化量が大きい場合には応 力增大に繫がり、ひび割れの危険性が高くなる。以上より、自己収 縮ひずみが大きく、かつ自己収維ひずみ全体に対してこの届曲点以 降の応力増大に寄与する自己収縮の割合が大きくなっているコンク リートは、ひび割れの危険性が高くなるものと考えられる。

次に、算出した累積クリープひずみと材龄の関係を図 13 に示す。 引張クリープ変形は従来よりひび割れ発生につながる重要な要因で あることが示されており、その発生メカニズムとして微小なひび割

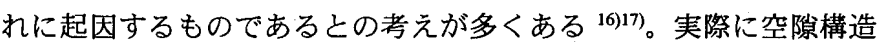

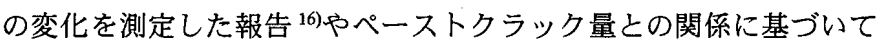
実証した報告 ${ }^{17)}$ みられる。したがって引張クリープ量が大きいほ ぞ微細ひび割れが増加・進展していき、ひび割れ発生につながって いくものと考えると、図 13 に示すように BB と Eのクリープは他と 比べて大きく、その結果ひび割れに至ったものと考えられ、N20も 同様にひび割㧈が発生しやすい状況にあると言える。一方、N25に ついては累積クリープひずみがこれらに比べて小さいことから、ま だその領域に至っていないことが推測できる。

応力強度比とクリープの関係については、クリープ破壊という観 点からは、継続して応力強度比の高い履歴を受けたコンクリートの 引張強度は、応力履歴を受けていない健全な場合の引張強度に比べ て低下すると考えられる。図 8 に示すようにそのような傾向が顕著 にみられたのは N20のみであるが、応力履歷なしの割裂引張強度と 直接引張強度が同等であると仮定すると、前述した考えに矛盾する ことになる。これらについての既往の研究では、水セメント比が $55 \%$ あるいは $60 \%$ 之高い領域で検討が行われており、根木らの報告 ${ }^{18)}$ においても似たような傾向が見受けられる。この中では、材踰 1〜7 日に載荷が開始された場合の引張強度比(載荷試験体の引張強度/無 載荷試験体の引(張強度)は、強度試験材跲が 14 日以前のものについ ては 1 を上回っている。その理由としては、引張クリープによる微 細ひび割れの進行と併せて若材齢では水和の進展による初期欠陥部 の修復が同時に起こるため、応力履歴の影響が相殺されているとの 考えを示している。これは、丸山ら ${ }^{19}$ の行った引張拘束を受けるセ メントペーストにおいて、載荷状態の方が結合水量が増大するとい う実験結果からも毫付けられる。狩野らの報告 9)では材踰 12〜24 時 間で応力強度比 $40 \sim 85 \%$ の載荷を 3 日間行い、引張試験を実施して いるが、いずれの場合も引張強度比はほぼ 1〜1.1の笧囲内であった。 以上の結果より、根木らが示したような現象は本実験でも生じてい ると思われ、N20のように若材秢時から $80 \%$ 以上となるきわめて高 い忘力強度比の履歴を受け続けた場合は、水和の修復作用を上回る 微細ひび割れが発生して引張強度が低下するが、それ以下の場合に は強度低下には大きな影響を及ぼさないことが言える。また、若材 齢時における水和の活発度からすると、本実験のような低水セメン ト比の方が久宿部の修復という効果は大きいものと思われる。

累積引張拘束ひずみと収縮応力の関係を図 14 に示す。N30 および N35 は、収縮応力のピーク後、除々にリラクゼーションによるもの と考えられる軟化の傾向を示し、応力減少過程の挙動が応力増大過 程と同一曲線状を逆に辿っている。これは、線形クリープの範囲で コンクリートは大きな損傷を受けていない健全な状態であることを 示唆しているものと考えられる。一方で、N20 は応力増加の曲線上
と乘離して応力低下が生じており、ひび割れ発生への遷移領域にあ る可能性が高い。これは、図 8 の健全な試験体による割裂引張強度 に対して応力強度比の高い履歴を受けた試験体の直接引張強度の割 合が低下していることを裏付けているものと推察できる。

以上、ひび割れが最も生じやすい完全拘束を再現して高強度コン クリートのひび割れ発生に至る自己収縮挙動について検討してきた が、今回ひび割れが生じた高炉セメント B 種やエコセメントはこの ような低水セメント比の調合で使用されるケースは少なく、あくま でも厳しい拘束下での条件であることを付記しておく。また、他の 調合に関しても水セメント比が小さい場合は自己収縮の影響のみで ひび割れが発生しなくとも、ある程度の自己収縮応力が発生してお り、脱型後の急激な乾燥収縮によってひび割れが生じることも十分 にあり得る。今後は、より実態に即した自己収縮に乾燥収縮の影響 を考慮した評価、さらには実構造物の拘束条件を再現した評価が必 要であると考えられる。

\section{4. まとめ}

本研究では、様々な材料を用いた高強度コンクリートを対象に擬 似完全拘束下における自己収縮ひび割れポテンシャルについて評価 した結果、以下の知見が得られた。

(1)応力履歴を受けたコンクリートの直接引張強度は、若材齢時に膨 張ひずみが拘束された膨張コンクリートにおいては割裂引張強 度より高くなり、材齢初期から極めて高い応力履歷を受けたコン クリートではひび割れが発生するか、あるいは直接引張強度の低 下が生じた。また、応力強度比が比較的低い場合の直接引張強度 は、割裂引張強度と同等以上となった。

(2) 上記理由として、引張クリープが微細ひび割れに起因するものと の立場をとると、低い応力履歴を受けたコンクリートは水和によ る修復作用が影響し、高い応力履歷を受けた場合はその修復作用 を上回る微細ひび割れが生じたものと考えられる。

（3）自己収縮によるひび割れには、自己収縮ひずみ量の絶対值が影響 するだけでなく、特に応力增大に寄与する見掛けのヤング係数が 急增する時点以降の、自己収縮ひずみの全自己収縮ひずみに対す る割合が影響している可能性を示した。

（4）累積引張拘束ひずみと収縮応力の関係より、材齢後半で拘束応力 がピークを示した後、応力減少過程の挙動が増大過程と同一曲線 状となった場合は、線形クリープの範囲で大きな損傷を受けてい ない健全な状態であることを示唆している。一方、同一曲線状と ならず乘離している場合は、強度低下に䡔がる損傷を受けている と考えられる。

\section{参考文献}

1）日本コンクリート工学協会 : コンクリートの自己収縮研究委員会報告書, pp.97-101, 2002

2) 早川智浩, 許明, 佐藤良一, 今本辟一: 高強度コンクリートラーメンの 自己収縮応力 2 次元 FEM 解析, コンクリート工学年次論文報告集 Vol.20, No.2, pp.1027-1032, 1998

3）䦥田徽志:ひび割れ発生条件, コンクリート工学, Vol.43, No.5, pp.60-66, 2005

4）日本建築学会：鉄筋コンクリート造建築物の収縮ひび割れ制御設計・施 
工指針案·同解説, pp.4-7, 2006

5) 日本コンクリート工学協会: 自己収縮研究委員会報告書, pp.195-198, 1996

6）丸山一平, 朴宣圭, 野口貴文: 蘶似完全拘束下における若材龄高強度コ ンクリートの性状に関する研究, コンクリート工学年次論文報告集, Vol.25, No.1, pp.485-490, 2003

7）丸山一平：コンクリートのひび割れ抵抗性測定を目的とした疑似完全拘 束試呀に関する研究, コンクリート工学, Vol. 45, No. 2, pp. 54-57, 2007

8）橋田浩, 山崎庸行 : 初期高温履歴を受ける高強度コンクリート構造体の 自己収縮応力の算定法に関する検討, 日本建策学会構造系論文集, No.537, PP.7-12, 2000.11

9) 特野敏也, 渡辺博志, 河野広隆 : 温度ひび割れ評価のためのコンクリー トの引張強度特性に関する研究, 土木学会第 50 回年次学術講演会梗概集, pp.732-733, 1995

10) 米田俊一, 竹田宣典, 十河茂幸, 芳賀孝成 : 各種低熱セメントを用いた コンクリートの伸び特性, 土木学会第 47 回年次学術講演会梗概集, pp.732-733, 1992

11）日本建築学会 : 鉄笳コンクリート造建筑物の収縮ひび割れーメカニズム と対策技術の現状一 付録, pp.94-95, 2003

12）日本コンクリート工学協会 : コンクリートの自己収縮研究委員会報告書, pp.106-107, 2002

13）森永繁: ひび割れ抑制技術の現状一対策と効果一, コンクリート工学, Vol.34, No.8, pp.13-20, 1996

14) Kovler, K., Testing system for determining the mechanical behaviour of early age concrete under restrained and free uniaxial shrinkage, Material and Structures, pp.324-330, 1994

15）日本コンクリート工学協会 : 自己収縮研究委員会報告書, pp.95-96, 1996

16) 熊野知司, 西林新藏, 井上正一, 吉野公 : コンクリートの空䍀構造の変 化に基づく引張クリープ予測モデルに関する研究，土木学会論文集， No.613, V-42, pp.121-135, 1999

17) 吉本彰, 長谷川博, 川上正史 : 引張クリープ機構に関する一研究, セメ ント技術年報 36, pp.333-336，1982

18）根木崇文, 入矢桂史郎, 梅原秀哲 : 若材齢のクリープがコンクリートの 引張破塄に与える影響に関する検討, コンクリート工学年次論文報告集, Vol.21, No.2, pp.757-762, 1999

19）丸山一平, 野口貴文, 朴 宣圭, 岡沢智: 引張拘束下におけるセメントの 結合水量增大現象に関する考察，セメント技術大会, pp.224-225, 2002 （2007年 5 月10日原稿受理，2007年 9 月 4 日採用決定） 